\title{
Possible diagnostic markers for Mucopolysaccharidoses; Cathepsin-D, Galectin-3 and Chitotriosidase
}

\section{Mukopolisakaridozlar için muhtemel tanısal belirteçler; Katepsin-D, Galektin-3 ve Kitotriosidaz}

\author{
Pelin ERGUN ${ }^{1}$, Mehtap KAĞNICI ${ }^{2}$, Sema KALKAN UÇAR ${ }^{3}$, Mahmut ÇOKER ${ }^{3}$, Yasemin DELEN AKÇAY ${ }^{1}$, \\ Eser YILDIRIM SÖZMEN ${ }^{1}$
}

${ }^{1}$ Ege Üniversitesi Tıp Fakültesi, Tıbbi Biyokimya Ana Bilim Dalı, İzmir

${ }^{2}$ Dr. Behçet Uz Çocuk Hastanesi, İzmir

${ }^{3}$ Ege Üniversitesi Tıp Fakültesi, Çocuk Sağlı̆̆ı ve Hastalıkları Ana Bilim Dalı, İzmir

\section{ABSTRACT}

\begin{abstract}
Objective: Mucopolysaccharidoses is a group of inherited lysosomal storage diseases that are manifested by various clinical signs and symptoms (skeletal dysplasia, coarse face, progressive psychomotor retardation, cardiac and lung involvement) due to the deposition of glycosaminoglycans in tissues. Recently it has been shown that the inflammatory response to glycosaminoglycan deposition in leucocytes in animal models of mucopolysaccaridoses has increased. Here, we aimed to investigate some inflammatory markers (galectin-3, cathepsin-D and chitotriosidase) as diagnostic markers in different types of mucopolysaccharidosis and in patients with Gaucher disease and Niemann Pick A/B disease.

Methods: Plasma samples were collected from patients with mucopolysaccharidosis $(n=25)$, Gaucher Disease $(n=16)$, Niemann Pick A/B $(n=5)$ and 15 healthy controls. All subjects were under the age of 18 years. Chitotriosidase enzyme activities were determined fluorometrically, cathepsin-D and galectin-3 levels were determined by using the ELISA kit.

Results: Chitotriosidase enzyme activities were statistically significantly higher in patients with MPS IV than the control group. Cathepsin-D levels were higher in patients with MPS I, MPS III and MPS IV, galectin-3 levels were higher in patients with MPS I, MPS IV and MPS VI when compared to healthy controls. All three parameters were higher in patients with Gaucher disease and Niemann Pick A/B disease.

Conclusion: Elevated levels of galectin-3 in MPS I, MPS IV and MPS VI and elevated levels of cathepsin-D in MPS I, MPS III and MPS VI support the influence of inflammatory process in the pathophysiology of mucopolysaccharidosis and might be promising new biomarkers in the diagnosis with high sensitivity and specificity.
\end{abstract}

Keywords: Cathepsin-D, Galectin-3, chitotriosidase, MPS, ELISA, Mucopolysaccharidoses

\section{$\ddot{0 z z}$}

Amaç: Mukopolisakkaridozlar dokulardaki glikozaminoglikanların birikimi nedeniyle çeşitli klinik belirti ve semptomlar (iskelet displazisi, seyir yüzü, ilerleyici psikomotor gerilik, kalp ve akciğer tutulumu) ile kendini gösteren kahtsal lizozomal depolama hastalıkları grubudur. Son zamanlarda, mukopolisakaridoz hayvan modellerinde lökositlerdeki glikosaminoglikan birikimine verilen enflamatuvar yanıtın arttı̆̆ı gösterilmiştir. Bu çalışmada, ceşitli mukopolisakaridoz tipleri ile Gaucher ve Niemann Pick A/B hastalıklarında bazı inflamatuvar proteinleri (galektin-3, katepsin-D ve kitotriozidaz) tanısal belirteç olarak araştırmayı ve bu proteinlerin düzeylerini karşılaştırmayı amaçladık.

Yöntem: Mukopolisakaridozlu 25 mukopolisakkaridoz, 16 Gaucher, 5 Niemann Pick A/B hastası ve 15 sağlıklı kontrolten plazma örnekleri alındı. Tüm denekler 18 yaşın altındaydı. Tüm hastalarda kitotriyozidaz enzim aktiviteleri florometrik olarak belirlendi. Kandaki katepsin-D ve galektin-3 seviyeleri, ELISA kiti kullanılarak belirlendi.

Bulgular: MPS IV hastalarında kitotriyozidaz enzim aktiviteleri, kontrol grubuna göre istatistiksel olarak daha yüksekti. MPS I, MPS III ve MPS IV hastalarında katepsin-D düzeyleri ve MPS I, MPS IV ve MPS VI hastalarında galektin-3 düzeyleri sağlıklı kontrollerle karşılaştırıldığında daha yüksekti. Gaucher hastalığı ve Niemann Pick A/B hastalarında üç parametrenin hepsi kontrollere göre anlamlı olarak artış göstermişti.

Sonuç: MPS I, MPS IV ve MPS VI hastalarında yüksek seviyelerde galektin-3 seviyeleri ve MPS I, MPS III ve MPS VI hastalarında artmış kathepsin-D seviyeleri, mukopolisakaridoz patofizyolojisinde inflamatuvar sürecin etkisini desteklemekte, yüksek duyarlılık ve özgünlük ile tanıda yeni bir biyolojik belirteç olarak kullanılmayı vadetmektedir.

Anahtar kelimeler: Katepsin-D, galektin-3, kitotriyozidaz, MPS, ELISA, Mukopolisakkaridoz
Alındı̆̆ı tarih: 15.03.2017

Kabul tarihi: 12.06 .2017

Yazışma adresi: Dr. Pelin Ergun, Ege Üniversitesi Tıp Fakültesi, Tıbbi Biyokimya Ana Bilim Dalı, Bornova, 35100, İzmir

e-mail: pelinergun@yahoo.com

International Meeting: (Poster)

Pelin Ergün, Mehtap Kağnıcı, Sema K. Uçar, Mahmut Çoker, Yasemin D. Akçay, Eser Y. Sözmen, "Cathepsin-D; A New Inflammation Biomarker In Diagnosis Of Lysosomal Storage Diseases" FEBS Advanced Lecture Course: $360^{\circ}$ Degree Lysosome, Kuşadast, Turkey (23-28 October 2014) 


\section{INTRODUCTION}

Mucopolysaccharidoses (MPS) is a rare group of inherited lysosomal storage diseases that are manifested by various clinical signs and symptoms (skeletal dysplasia, coarse face, progressive psychomotor retardation, cardiac and lung involvement) due to the deposition of glycosaminoglycans in tissues ${ }^{(1)}$. They are diagnosed by determining the glycosaminoglycans in urine and the depleted enzyme activity in DBS (dried blood spot) samples or leucocytes of the patients and verified genetic testing. There is an active interest in identifying biomarkers that can serve as a surrogate for or indicator of disease severity, in terms of either overall disease burden or involvement of particular system.

Chitotriosidase (CHIT) is synthesized by neutrophilic granulocyte progenitors and it has been proposed to be a biochemical marker of macrophage activation in several lysosomal diseases especially Gaucher's disease and Niemann Pick type A/B ${ }^{(2,3)}$.

Cathepsin-D (Cat-D) is a lysosomal aspartyl protease that is composed of two disulfide-linked polypeptide chains, both produced from a single protein precursor ${ }^{(4)}$. Cat-D has spacious substrate specificity at acidic $\mathrm{pH}$ which leads to degradation of proteins and composition of mature activated peptides in endosomes ${ }^{(5)}$.

Galectin-3 (Gal-3) is a carbohydrate-binding protein which mediates cell-cell and cell-extracellular matrix (ECM) interactions ${ }^{(6)}$. Gal-3 is not only an intracellular protein that can be found both in the cytoplasm and nucleus but it is also an extracellular protein that can be present on the cell surface or the extracellular matrix ${ }^{(7)}$.

Cluzeau et al investigated a subset of 103 differentially expressed genes in Niemann Pick type C1 patients to identify any potential markers for diagnosis and monitoring of treatment of patients, and they found an upregulation of expression of serum galectin-3 and serum cathepsin-D levels which were correlated with neurological disease severity ${ }^{\left({ }^{(8)}\right.}$. Hence, we determined the galectin- 3 and cathepsin-D levels in patients with mucopolysaccharidosis who showed neuorological manifestations characterized by microglial activation in animal models. Additionally, we aimed to investigate Cat-D, Gal-3 and CHIT serum levels in patients with Gaucher and Niemann Pick A/B disease to compare with MPS patients.

The glycosaminoglycans (GAGs) accumulate in the lysosomes of bone, cartilage, and ligaments and in the extracellular matrix (ECM) in people with MPS. Since excess GAG accumulation stimulates metabolic inflammation, we aimed to investigate whether cathepsin-D (a lysosomal protease), galectin-3 and chitotriosidase (marker of macrophage activation) could be the novel biomarkers in patients with MPS.

\section{MATERIALS and METHODS}

Subjects: To evaluate potential biomarkers for mucopolysaccharidosis, this study examined plasma samples obtained from 15 healthy controls, and 46 patients (Gaucher Disease, $n=16$; Niemann Pick A/B, $n=5$; MPS I, $n=4$; MPS II, $n=3$; MPS III $(n=4)$, MPS IVA, $n=7$ and MPS VI, $n=7$ ) not receiving enzyme replacement treatment (ERT). All patients had received an enzyme-confirmed diagnosis of the indicated diseases. The protocol was approved by the Ethical Committee of Ege University School of Medicine (13-3.1/4, 19.03.2013). Informed consent was obtained from all participants and/or their parents.

Inclusion criteria were under aged 18 years, normal renal function, no clinical or laboratory signs of an inflammatory disease, LSD diagnosis verified by genetic test and not having been treated with ERT within the last 6 months.

Blood sampling: $2 \times 2 \mathrm{cc}$ of fasting blood was collected by venous arm puncture under aseptic conditions into EDTA-tubes. Plasma was obtained by centrifugation at $2000 \mathrm{~g}$ for $5 \mathrm{~min}$. Plasma was kept at $-20^{\circ} \mathrm{C}$ until the day of analysis.

Determination of Cathepsin-D levels: According to the manufacturer's instructions, sandwich enzymelinked immunosorbent assay (ELISA) was used for the measurement of plasma cathepsin-D levels (Human Cathepsin-DELISAkitBosterImmunoleader, Pleasanton, CA, Cat. Number: EK0672). Before performing the assay, blood samples were stored at $2-8^{\circ} \mathrm{C}$ for 24 hours. Plasma was diluted 10 times with 
dilution buffer.

Determination of Chitotriosidase activities: Plasma chitotriosidase (CHIT) activities were determined fluorometrically by the method of Chamoles et al. ${ }^{(9)}$ with sample blank correction. After the addition of citrate-phosphate buffer ( $\mathrm{pH} 4.4)$ to the $5 \mu \mathrm{L}$ of the samples, 20 $\mu$ lof4-MU-C3(4-methylumbelliferyl $\beta$-d-N,N,N"-triacetylchitotrioside, $19 \mathrm{mmol} / \mathrm{L})$, distilled water and $20 \mu \mathrm{l}$ of acetate buffer $(0.5 \mathrm{mmol} / \mathrm{L}$, $\mathrm{pH}$ 5.0) were added to the samples and mixed. The samples were incubated for $30 \mathrm{~min}$ at $37^{\circ} \mathrm{C}$. The reactions were stopped by adding $200 \mu 1$ of ethylenediamine. All readings (excitation at $365 \mathrm{~nm}$ and emission at $450 \mathrm{~nm}$ ) were performed on a Modulus microplate fluorometer (Turner Biosystems, Sunnyvale, USA), and all calculations were performed using a calibration curve of 4-methylumbelliferone as the calibrator. The samples from a healthy person and a confirmed patient were used as positive and negative internal quality control in each assay run.

Determination of Galectin-3 levels: According to the manufacturer's instructions, sandwich enzymelinked immunosorbent assay (ELISA) was used for the measurement of plasma galectin-3 levels (Human Galectin-3 ELISA Kit Aviscera Bioscience, Inc., Santa Clara, USA).

Statistical analysis: All data were evaluated using SPSS 22.0 statistics program (version 22.0, IBM, Chicago, IL, USA). A one-way ANOVA was performed to check for significant differences in analytes between patients and unaffected control subjects. Descriptive statistics were used to see the range of the values (maximum-minimum) and means. Mann Whitney-u test was used to compare mean activity between patients and controls.

\section{RESULTS}

Table 1 summarizes the demographic information for patients and 15 unaffected controls in this biomarker study. The mean ages for controls and total patients were $13.7 \pm 8.06$ and $9.22 \pm 1.89$ years.

Table 2 presents the Chitotriosidase activity, cathepsin-D and galectin-3 levels.

Cathepsin-D levels were significantly higher in
Table 1. The demographic information for patients and unaffected controls.

\begin{tabular}{lcccc}
\hline Subjects & $\begin{array}{c}\text { N (Male/ } \\
\text { Female) }\end{array}$ & Age & $\begin{array}{c}\text { Height } \\
(\mathbf{c m})\end{array}$ & $\begin{array}{c}\text { Weight } \\
(\mathbf{k g})\end{array}$ \\
\hline MPS I & $4(-/ 4)$ & $6,00 \pm 3,50$ & $81,7 \pm 19,5$ & $10,5 \pm 6,4$ \\
MPS II & $3(3 /-)$ & $11,00 \pm 2,65$ & $109,5 \pm 19,1$ & $22,7 \pm 4,7$ \\
MPS III & $4(1 / 3)$ & $10,00 \pm 4,32$ & $113,0 \pm 35,6$ & $29,3 \pm 8,1$ \\
MPS IVA & $7(2 / 5)$ & $9,57 \pm 5,13$ & $92,6 \pm 6,3$ & $16,0 \pm 3,5$ \\
MPS VI & $7(3 / 4)$ & $9,57 \pm 3,95$ & $93,3 \pm 9,4$ & $19,2 \pm 6,4$ \\
Gaucher & $16(4 / 12)$ & $18,6 \pm 14,2$ & $130,6 \pm 35,1$ & $37,5 \pm 24,5$ \\
Niemann Pick & $8(3 / 5)$ & $5,9 \pm 3,9$ & $119,0 \pm 37,0$ & $25,0 \pm 19,2$ \\
A/B & & & & \\
Controls & $15(7 / 8)$ & $15,13 \pm 8,64$ & $103,80 \pm 24,07$ & $17,30 \pm 8,22$ \\
& & & & \\
\hline
\end{tabular}

Table 2. Chitotriosidase activities, Cathepsin-D and Galectin-3 levels.

\begin{tabular}{lccc}
\hline & $\begin{array}{c}\text { Cathepsin-D } \\
(\mathbf{n g} / \mathbf{m L})\end{array}$ & $\begin{array}{c}\text { Chitotriosidase } \\
(\mathbf{n m o l} / \mathbf{m L} / \mathbf{h})\end{array}$ & $\begin{array}{c}\text { Galectin-3 } \\
(\mathbf{n g} / \mathbf{m L})\end{array}$ \\
\hline Healthy Control & $167,9 \pm 40,7$ & $65,5 \pm 37,4$ & $2474 \pm 1095$ \\
MPS I & $467,3 \pm 377,3^{*}$ & $80,8 \pm 46,5$ & $4946 \pm 617^{*}$ \\
MPS II & $224,3 \pm 51,1$ & $73,4 \pm 58,6$ & $4220 \pm 2486$ \\
MPS III & $357,5 \pm 49,0^{*}$ & $150,0 \pm 115,2$ & $3760 \pm 1437$ \\
MPS IV & $325,9 \pm 131,5^{*}$ & $400,9 \pm 299,0^{*}$ & $4018 \pm 1752^{* *}$ \\
MPS VI & $204,6 \pm 56,9$ & $148,7 \pm 207,3$ & $4584 \pm 1140^{*}$ \\
Gaucher & $348,5 \pm 130,3^{*}$ & $6226,3 \pm 4935^{*}$ & $4310 \pm 2184^{*}$ \\
Niemann Pick A/B & $455,4 \pm 202,1^{*}$ & $2548 \pm 1359 *$ & $5026 \pm 1874 *$ \\
& & &
\end{tabular}

Data represents mean \pm S.D. Comparisons were made versus to healthy controls. Mann whitney-u test, ${ }^{*} p<0.01,{ }^{* *} p<0.05$.

patients with Gaucher disease $(\mathrm{p}=0.01)$, Niemann Pick A/B disease ( $p=0.002)$, MPS I $(p=0.002)$, MPS III $(p=0.001)$ and MPS IVA $(p=0.01)$ versus unaffected controls. Cathepsin-D levels of patients with MPS II ( $p=0.097)$ and MPS VI $(p=0.078)$ were also higher than the control group without any statistically significant difference.

There were no subjects having zero chitotriosidase activity due to genetic deficiency. Plasma chitotriosidase activities were statistically significant higher in patients with Gaucher Disease $(p=0.000)$ and Niemann Pick A/B disease $(\mathrm{p}=0.000)$ compared to controls. Chitotriosidase activities were not significantly different between all of the MPS subjects except MPS IVA $(\mathrm{p}=0.005)$.

Plasma galectin-3 levels were significantly higher in patients with Gaucher disease $(p=0.014)$, Niemann Pick A/B disease ( $p=0.008)$, MPS I ( $p=0.001)$, MPS $\operatorname{IVA}(\mathrm{p}=0.047)$ and in patients with MPS VI $(\mathrm{p}=0.005)$ 

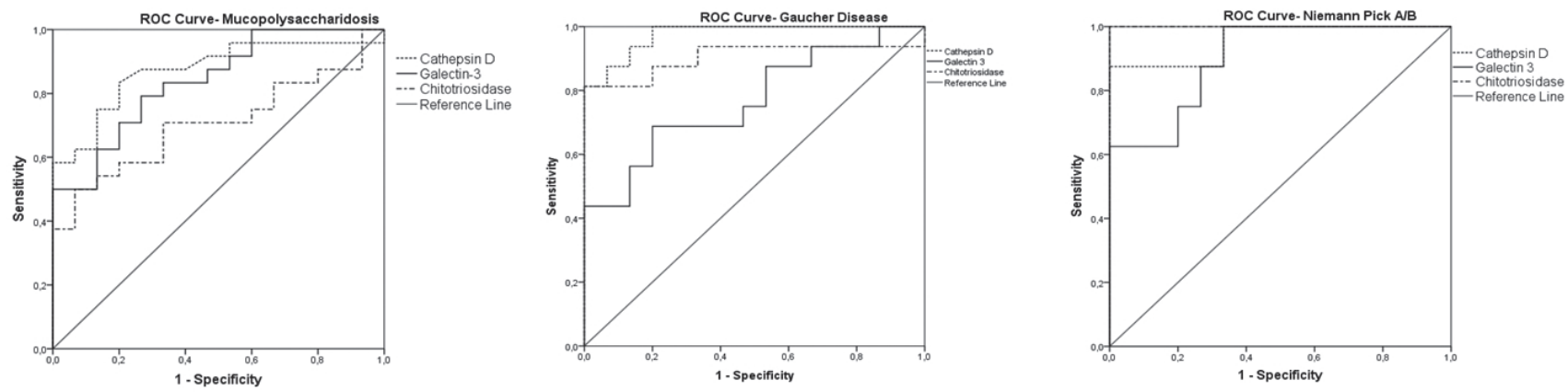

\begin{tabular}{|l|l|l|}
\hline MPSs & AUC & Sign. \\
\hline Cathepsin D & 0,872 & $\mathrm{P}=0,000$ \\
\hline Galectin 3 & 0,839 & $\mathrm{P}=0.000$ \\
\hline Chitotriosidase & 0,706 & $\mathrm{P}=0.033$ \\
\hline
\end{tabular}

\begin{tabular}{|l|l|l|}
\hline Gaucher & AUC & Sign. \\
\hline Cathepsin D & 0,975 & $\mathrm{P}=0,000$ \\
\hline Galectin 3 & 0,767 & $\mathrm{P}=0.011$ \\
\hline Chitotriosidase & 0,904 & $\mathrm{P}=0.000$ \\
\hline
\end{tabular}

\begin{tabular}{|l|l|l|}
\hline NP A/B & AUC & Sign. \\
\hline Cathepsin D & 0,958 & $\mathrm{P}=0,000$ \\
\hline Galectin 3 & 0,900 & $\mathrm{P}=0.002$ \\
\hline Chitotriosidase & 1,000 & $\mathrm{P}=0.000$ \\
\hline
\end{tabular}

Figure 1. ROC curves and AUC levels for Plasma Cathepsin-D, Galectin-3 and chitotrosidase.

versus the healthy controls. Galectin-3 levels in plasma of patients with MPS II and III did not show any significant change when compared to controls.

ROC curves and Area Under the Curve (AUC) levels within 95\% confidence Interval for these parameters were presented in Figure 1. Due to the limited number of patients in each group, we formed ROC curve for Gaucher, Niemann Pick A/B and all MPS patients. While AUC levels of all of three parameters (Chitotriosidase activity, Cathepsin-D and Galectin 3 levels) showed high values for Gaucher and Niemann Pick A/B disease, AUC levels of galectin-3 and cathepsin-D levels were more significant than chitotriosidase activity for MPSs.

\section{DISCUSSION}

In this study, we investigated the cathepsin-D, galectin-3 levels and chitotriosidase enzyme activity as potential biomarkers for mucopolysaccharidosis and Gaucher and Niemann Pick A/B disease. We observed an increase in galectin-3 levels in patients with MPS I, MPS IV, MPS VI and an increase in cathepsin-D levels in patients with MPS I, MPS III and MPS IV for the first time. Chitotriosidase activity was elevated only in MPS IV patients.

Chitotriosidase produced by activated macropha- ges is a well-known biomarker in the diagnosis and management of patients with Gaucher disease. Our data showed that CHIT levels were significantly higher in patients MPS IVA as well as Gaucher and Niemann Pick disease. There was no statistically significant difference between the controls and other mucopolysaccharidosis. Consistent with our findings, Isman et al reported no significant change in chitotriosidase activity in patients with mucopolysaccharidosis ${ }^{(16)}$. However, they found only one of two patients with MPS IVA had significantly high chitotriosidase activity. Donida et al showed increased plasma IL-6 levels of MPS IVA patients compared to controls and they suggested the presence of a proinflammatory state which was supported by our findings ${ }^{(17)}$. MPS IVA diagnosis is mostly delayed and has some challenges due to the variable severity of the clinical presentations, high rate of false negative results in urine GAG testing, the presence of other diseases (multiple sulfatase deficiency; MSD) and mucolipidosis II or III (ML I/III) together with the deficiency of GALNS [galactosamine (Nacetyl)-6sulfatase] activity ${ }^{(18)}$. Determination of chitotriosidase activity, galectin-3 and cathepsin-D levels in addition to GALNS activity and urine GAG might have an diagnostic value in these patients.

Although inflammatory nature of Gaucher and 
Niemann Pick disease has been clearly recognized the inflammatory processes of mucopolysaccaridoses have not been clearly defined yet in humans. Some authors showed a link between the intralysosomal glycosaminoglycan accumulation and inflammatory process in animal models of MPS IIIA, MPS VI and VII ${ }^{(10,11)}$. Simoaro et al. ${ }^{(11)}$ demonstrated that glycosaminoglycan accumulation leads to release of cytokines, chemokines, proteases and nitric oxide from lysosomes of mice with MPS VI and VII. Ohmi et al. (12) observed microglia activation due to glycosaminoglycan accumulation in lysosomes in mouse models of MPS I and IIIB. Accumulated heparin and heparan sulfate in the brain of MPS III mice might either directly activate microglia or play a role in activation of microglia through stimulating macrophages ${ }^{(10)}$. It has been suggested that microglial activation and astroglial activation led to macrophage activation resulting in the release of chemokines and cytokines, which are responsible mediators in neurodegenerative processes.

Cathepsin-D is a lysosomal aspartic protease, secreted as procathepsin-D by activated microglia and proenzyme has a role in the inflammation mediated neurodegeneration ${ }^{(13)}$. Recently Beckman et al. (14) showed that GAGs, in particular, heparin stimulated both proenzyme and cathepsin-D under in vitro conditions. They speculated that the activation of cathepsin-D by glycosaminoglycan was closely related to the number of negative charges of molecules rather than the specific position of sulphate group in the proteoglycan molecule. Consistent with this finding, we demonstrated elevated levels of cathepsin-D in all type of MPS patients, and this elevation was more significant in patients with MPS I, MPS III and MPS IV characterized by accumulation of heparan sulphate and keratan sulphate. Although the activity of cathepsin-D in patients with MPS II and MPS VI increased, this elevation was not statistically significant, and may be due to the limited number of patients for MPS II $(n=3)$. It remained unclear whether the type of proteoglycan has any different effect on cathepsin-D production.

Galectin-3 is a lectin protein, which is released by activated macrophages and has both intracellular (signalling pathways and modulation of cell migration) and extracellular functions (cell adhesion, cytokine production and modulation of receptor function ${ }^{(15)}$. Madrigal-Matute et al. ${ }^{(15)}$ showed that galectin-3 was released by activated monocytes under in vivo and in vitro conditions. Gal-3 release increased while macrophages were loaded with lipids. In accordance with this finding we showed an increase in galectin-3 levels in patients with Gaucher and Niemann Pick disease which was characterized by the accumulation of lipid loaded macrophages. Similarly, lysosomes loaded by glycosaminoglycan in mucopolysaccharidosis might induce expression and release of galectin-3. We determined a statistically significant increase in Gal-3 levels in patients with MPS I, MPS IVA and MPS VI. In the present study the Gal-3 levels of MPS II $(n=3)$ and MPS III $(n=4)$ patients were about two fold higher compared to the controls, however the elevation in the levels was not statistically significant, probably due to the limited number of patients.

ROC curves for these proposed markers supported the diagnostic efficacy of especially Gal-3 and cathepsin-D in cases with mucopolysacharidosis. However because of the limited number of patients, ROC curves for each disease could not be drawn separately.

In conclusion, our data suggested galectin-3, cathepsin-D and chitotriosidase as new laboratory markers for the diagnosis of mucopolysaccharidosis. Although the clarification of any possible relationship between the severity of disease and biomarker levels and possible effect of treatment need further investigations, we propose that the determination of galectin-3 levels in MPS I and MPS VI and cathepsin-D levels in MPS I, MPS III and MPS IV might have predictive value in the diagnosis and also be helpful for the management of these diseases.

Acknowlegement: This research was supported by Ege University Research Foundation (13 TIP-013).

Conflict of interest: The authors (P. Ergun, M. Kagnici, S.K. Ucar, M. Coker, Y.D. Akcay and E.Y. Sozmen) declare that they have no conflict of interest. 


\section{REFERENCES}

1. Pastores GM. Lysosomal Storage Disorders: principles and Practice. 2010.

2. Hollak CEM, Vanweely S, Vanoers MHJ and Aerts JMFG. Marked Elevation of Plasma Chitotriosidase Activity - a Novel Hallmark of Gaucher Disease. J Clin Invest 1994;93:1288-92. https://doi.org/10.1172/JCI117084

3. Sheth JJ, Sheth FJ, Oza NJ, Gambhir PS, Dave UP and Shah RC. Plasma chitotriosidase activity in children with lysosomal storage disorders. Indian J Pediatr 2010;77:203-5. https://doi.org/10.1007/s12098-009-0249-0

4. Gieselmann V, Pohlmann R, Hasilik A and Vonfigura K. Biosynthesis and Transport of Cathepsin-D in Cultured Human-Fibroblasts. Journal of Cell Biology 1983;97:1-5. https://doi.org/10.1083/jcb.97.1.1

5. Benes P, Vetvicka V and Fusek M. Cathepsin D-Many functions of one aspartic protease. Crit Rev Oncol Hemat 2008;68:12-28. https://doi.org/10.1016/j.critrevonc.2008.02.008

6. de Oliveira JT, Ribeiro C, Barros R, et al. Hypoxia Up-Regulates Galectin-3 in Mammary Tumor Progression and Metastasis. PLoS One 2015;10:e0134458. https://doi.org/10.1371/journal.pone.0134458

7. Patterson RJ, Wang WZ and Wang JL. Understanding the biochemical activities of galectin- 1 and galectin- 3 in the nucleus. Glycoconjugate J 2002;19:499-506. https://doi.org/10.1023/B:GLYC.0000014079.87862.c7

8. Cluzeau CV, Watkins-Chow DE, Fu R, et al. Microarray expression analysis and identification of serum biomarkers for Niemann-Pick disease, type C1. Hum Mol Genet 2012;21:3632-46. https://doi.org/10.1093/hmg/dds193

9. Chamoles NA, Blanco M, Gaggioli D and Casentini C. Gaucher and Niemann-Pick diseases - enzymatic diagnosis in dried blood spots on filter paper: retrospective diagnoses in newborn-screening cards. Clin Chim Acta 2002;317:191-7. https://doi.org/10.1016/S0009-8981(01)00798-7
10. Arfi A, Richard M, Gandolphe C, Bonnefont-Rousselot D, Therond $\mathrm{P}$ and Scherman D. Neuroinflammatory and oxidative stress phenomena in MPS IIIA mouse model: The positive effect of long-term aspirin treatment. Molecular Genetics and Metabolism 2011;103:18-25. https://doi.org/10.1016/j.ymgme.2011.01.015

11. Simonaro CM, D'Angelo M, He XX, et al. Mechanism of glycosaminoglycan-mediated bone and joint disease Implications for the mucopolysaccharidoses and other connective tissue diseases. Am J Pathol 2008;172:112-22. https://doi.org/10.2353/ajpath.2008.070564

12. Ohmi K, Greenberg DS, Rajavel KS, Ryazantsev S, Li HH and Neufeld EF. Activated microglia in cortex of mouse models of mucopolysaccharidoses I and IIIB. P Natl Acad Sci USA 2003;100:1902-7. https://doi.org/10.1073/pnas.252784899

13. Kim S, Ock J, Kim AK, et al. Neurotoxicity of microglial cathepsin D revealed by secretome analysis. J Neurochem 2007; 103:2640-50. https://doi.org/10.1111/j.1471-4159.2007.04995.x

14. Beckman M, Freeman C, Parish CR and Small DH.Activation of cathepsin D by glycosaminoglycans. Febs J 2009;276:734352. https://doi.org/10.1111/j.1742-4658.2009.07444.x

15. Madrigal-Matute J, Lindholt JS, Fernandez-Garcia CE, et al. Galectin-3, a Biomarker Linking Oxidative Stress and Inflammation With the Clinical Outcomes of Patients With Atherothrombosis. J Am Heart Assoc 2014;3. https://doi.org/10.1161/JAHA.114.000785

16. Isman F, Natowicz MR, Hobert JA, Natowicz MR, Thompson $\mathrm{JN}$ and Natowicz MR. Plasma chitotriosidase in lysosomal storage diseases. Clin Chim Acta 2008;387:165-7. https://doi.org/10.1016/j.cca.2007.07.019

17. Donida B, Marchetti DP, Biancini GB, et al. Oxidative stress and inflammation in mucopolysaccharidosis type IVA patients treated with enzyme replacement therapy. Bba-Mol Basis Dis 2015;1852:1012-9. https://doi.org/10.1016/j.bbadis.2015.02.004

18. Wood TC, Harvey K, Beck M, et al. Diagnosing mucopolysaccharidosis IVA. J Inherit Metab Dis 2013;36:293-307. https://doi.org/10.1007/s10545-013-9587-1 